Kwartalnik Językoznawczy 2014/2

DOI : $10.14746 / \mathrm{kj} .2014 .2 .1$

Sonia Behrendt-Bartkowska

\title{
Morfologiczna adaptacja zapożyczeń greckich i lacińskich przez język polski i rosyjski
}

Od średniowiecza języki klasyczne w znaczący sposób wpływały na język polski i rosyjski. Oddziaływanie języka łacińskiego na polszczyznę rozpoczęło się wraz z przyjęciem chrześcijaństwa i stopniowo nasilało się, aż osiagnęło punkt kulminacyjny w XVI i XVII stuleciu. W wiekach późniejszych nastąpiło ograniczenie tych wpływów, jednakże słownictwo o łacińskiej proweniencji nadal odgrywa istotną rolę we współczesnym systemie leksykalnym języka polskiego. Natomiast o bezpośrednich oddziaływaniach greki na polszczyznę można powiedzieć niewiele, ponieważ większość słów wywodzących się z tego języka przedostała się za sprawą łacińskiego medium. W ruszczyźnie z kolei sytuacja kształtuje się nieco inaczej, ponieważ od drugiej połowy IX wieku Ruś Kijowska utrzymywała kontakt z Grekami, który związany był z wyprawami zbrojnymi oraz handlem. Przyjęcie chrześcijaństwa w obrządku prawosławnym w X stuleciu spowodowało, że w okresie staroruskim znaczna część słownictwa przedostawała się bezpośrednio z greki. W późniejszych wiekach część grecyzmów była zapożyczana pośrednio przy udziale innych języków europejskich. O bezpośrednim wpływie łaciny na język rosyjski możemy mówić dopiero od XVI wieku (wtedy bowiem zaczęto tłumaczyć teksty łacińskie), a najwięcej latynizmów lub greko-latynizmów przeniknęło do ruszczyzny za panowania cara Piotra I. Od połowy XVIII wieku, podobnie jak w polszczyźnie, odnotowuje się tendencję ograniczającą przejmowanie pożyczek z języków klasycznych. 
Celem niniejszego artykułu jest analiza wybranych różnic morfologicznych widocznych w procesie adaptacji wspólnych greckich, łacińskich i greko-łacińskich pożyczek na gruncie obu języków słowiańskich. Wnikliwemu oglądowi zostaną poddane różnice słowotwórcze, które w konsekwencji wpłynęły na rodzaj gramatyczny oraz sposób odmiany wyekscerpowanych leksemów.

Źródłem materiału do badań słownictwa wspólnego jest Słownik kieszonkowy polsko-rosyjski $i$ rosyjsko-polski zredagowany przez Inessę Mitronową, Galinę Sinicynę oraz Gienrikę Lipkies i wydany w Moskwie w 1975 roku. Ze względu na zawartą w nim liczbę haseł uznany został za słownik minimum. Rejestruje on zasób leksyki, który umożliwia zaspokojenie podstawowych potrzeb w różnych sytuacjach komunikacyjnych. W słowniku, zawierającym 11 tysięcy haseł, odnotowano 681 wspólnych dla języka polskiego i rosyjskiego zapożyczeń o greckiej lub łacińskiej proweniencji, co stanowi w przybliżeniu 6,2\% całego słownictwa. W 119 wyrazach (ponad 17\% wyselekcjonowanej leksyki wspólnej) nie odnotowuje się żadnych modyfikacji. Pozostałe, czyli ok. 83\% zapożyczeń, wykazują różnice w adaptacji morfologicznej lub fonetycznej na gruncie każdego z języków.

W tym artykule za wspólne zapożyczenia leksykalne uznaję:

1. Autosemantyzmy przejęte $\mathrm{z}$ greki i łaciny do języka polskiego i rosyjskiego na drodze impostacji, czyli przeniesienia leksemów w oryginalnej postaci fonetycznej i graficznej, wykazujące zgodność semantyczną;

2. Zapożyczenia przyswojone - rozumiane jako wyrazy mające wspólne centrum znaczeniowe oraz wspólną podstawę słowotwórczą; moga one zawierać modyfikacje o charakterze morfologicznym i fonetycznym, które powstały w wyniku rozwoju obu języków słowiańskich;

3. Wyrazy zapożyczone przy pośrednictwie innych języków europejskich;

4. Derywaty od greckich i łacińskich podstaw utworzone na gruncie innych języków zachodnioeuropejskich;

5. Wyrazy złożone będące kompilacją dwóch lub więcej podstaw łacińskich lub greckich. 


\section{Lacińska końcówka -um}

Pożyczki łacińskie i grecko-łacińskie zawierające końcówkę -um były w odmienny sposób przyswajane przez dwa zróżnicowane pod względem morfologicznym języki słowiańskie. W polszczyźnie nadal funkcjonuje grupa rzeczowników rodzaju nijakiego, która zachowała łaciński morfem -um, są to m.in.: akwarium, album ${ }^{1}$, ambulatorium, archiwum, audytorium, centrum, herbarium, honorarium, kolegium, konserwatorium, kryterium, laboratorium, liceum, mauzoleum, mиzeum, obserwatorium, plenum, prezydium, seminarium, stadium, terytorium.

$\mathrm{Na}$ gruncie języka rosyjskiego w tym typie zapożyczeń można częściej zaobserwować ślady przeprowadzonych zmian o charakterze morfologicznym:

1. W wyekscerpowanym materiale w czterech leksemach odnotowuje się włączenie łacińskiej końcówki do podstawy rzeczowników, w wyniku czego doszło do zmiany rodzaju gramatycznego z nijakiego na męski. Zmiana ta nastąpiła w wyrazach: akwarium - аквариум, plenuт - пленум, prezydium - президиум, tеchnikит - техникум.

2. Odrzucenie końcówki -um dokonane w takich rosyjskojęzycznych słowach, jak: архив, гонорар, семинар, центр spowodowało równocześnie zmianę rodzaju gramatycznego z nijakiego na męski.

3 . W języku rosyjskim łaciński morfem -um został zastapiony końcówką -uŭ lub -ě̆, co sprawiło, że ta grupa wyrazów odmienia się według wzoru II deklinacji (второе склонение) ${ }^{2}$. W słowniku bazowym pięć leksemów ilustruje ową zmianę: гербарий ('herbarium'), критерий ('kryterium'), лицей ('liceum'), мавзолей³ ('mauzoleum'), музей ('muzeum').

1 W języku polskim w wyrazie album łacińska końcówka została włączona do podstawy leksykalnej, a końcówki fleksyjne dodawane są do postaci album. Jest to rzeczownik rodzaju męskiego. Do zmiany rodzaju gramatycznego najprawdopodobniej doszło w XIX wieku pod wpływem wymawiania tego słowa zgodnie z fonetyką francuską [albom].

2 B. Chlebda, I. Danecka, T. Milutina, Имя существительное, w: iidem, Skrypt do praktycznej nauki języka rosyjskiego dla studentów I roku filologii rosyjskiej, Opole 2007, s. 91.

3 Max Vasmer wskazuje, że wyraz ten został zapożyczony przy pośrednictwie języków zachodnioeuropejskich: niemieckiego, francuskiego lub bezpośrednio $\mathrm{z}$ łaciny. Wymowa dyftongu au jako av mogłaby sugerować greckie pośrednic- 
4. Morfem -um w języku rosyjskim został także zastąpiony końcówką - $и я$, charakterystyczną dla rzeczowników rodzaju żeńskiego odmieniających się według wzoru deklinacji I miękkiej ${ }^{5}$. W wyodrębnionej bazie leksykalnej występują następujące słowa zawierające cząstkę -ия: аудитория ('audytorium'), коллегия ('kolegium'), консерватория ('konserwatorium'), лаборатория ('laboratorium'), обсерватория ('obserwatorium'), стадия ('stadium'), территория ('terytorium').

5. Za nietypową osobliwość leksykalną można uznać wyraz альбом ${ }^{6}$, ponieważ -um zostało przekształcone w -ом. Cząstka -ом jednakże nie stanowi odrębnej końcówki fleksyjnej: została włączona do tematu fleksyjnego, wobec tego wyraz ten odmienia się w sposób identyczny jak rzeczowniki rodzaju męskiego zakończone zerem morfologicznym. Zmiana ta prawdopodobnie zaszła pod wpływem francuskiej wymowy wyrazu album.

6. Autorzy Stownika kieszonkowego polsko-rosyjskiego i rosyjsko-polskiego uznali, że leksemy polski trofea i rosyjski mрофея w obu językach są przykładami rzeczowników pluralia tantum. W polszczyźnie wyraz ten rzeczywiście dość często występuje w formie liczby mnogiej ${ }^{7}$ (trofea), choć ma również liczbę pojedynczą (trofeum) zgodną z łacińskim odpowiednikiem. W języku rosyjskim w zależności od kontekstu można używać tego rzeczownika w obu formach: трофея i трофей. Leksemy w obydwu językach różnią się przede wszystkim rodzajem gramatycznym, w języku polskim wyraz ten zaliczany jest do rzeczowników rodzaju nijakiego, natomiast

two. Por. М. Фасмер, Этимологический словарь русского языка, t. 2, Moskwa 1987, s. 554 [dalej: ESJR].

4 Według notacji Vasmera wyraz музей zapożyczono do języka rosyjskiego przy udziale polskiego lub niemieckiego pośrednictwa. Jest to pośrednia pożyczka łacińska, wyklucza się możliwość zapożyczenia tego wyrazu z greki. Por. ESJR, t. 3, s. 6.

5 M. Froelichowa, M. Kwiatkowski, S. Łaszewski, Deklinacja pierwsza (nepвoe склонение), w: iidem, Gramatyka języka rosyjskiego, Warszawa 1962, s. 38.

6 Wyraz ten przedostał się do języka rosyjskiego za pośrednictwem języka francuskiego. Por. альбом [hasło], w: ESJR, t. 1, s. 74.

7 Por. trofeum [hasło], w: Stownik jezzka polskiego, red. W. Doroszewski, t. 1-11, Warszawa 1958-1969, wersja online: http://doroszewski.pwn.pl/haslo/ /trofeum [dostęp: 24.04.2014]. 
w języku rosyjskim mpoфeü ${ }^{8}$ występuje w rodzaju męskim, ponieważ łacińska końcówka -um została zastąpiona - $(e) \check{u}$.

\section{Lacińska końcówka -us i -ius}

W formach źródłowych wielu latynizmów zapożyczanych do obu języków występował morfem -us, jednakże w zgromadzonym polskim materiale leksykalnym końcówka ta przetrwała jedynie w wyrazach spirytus (łac. spiritus) i tyfus (gr. typhos, łac. typhus), jako część tematu. W rosyjskojęzycznym wariancie leksemu muф doszło do derywacji wstecznej. Natomiast słowo cnupm $^{9}$ do języka rosyjskiego zostało zapożyczone nie z łaciny, ale z języka angielskiego, w którym funkcjonowała już forma niezawierająca łacińskiej końcówki -us.

Latynizm sanitarius w języku polskim funkcjonuje w prawie niezmienionej formie sanitariusz ${ }^{10}$. Najprawdopodobniej rosyjskojęzyczny wyraz caнumap nie powstał w wyniku odcięcia końcówki -us. Vasmer oraz Nikolaj Gorjajev wskazują, że podstawą słowotwórczą tego wyrazu jest francuski leksem sanitaire, do którego dodano morfem $-a r^{11}$. Opinia obu językoznawców o tyle nie przekonuje, że cząstka -ar obecna jest już w słowie francuskim.

Od łacińskiej frazy annus iubilaeus ${ }^{12}$, oznaczającej rok jubileuszowy, powstały wyrazy w łacinie (iubilaeus), języku polskim (jubileusz) oraz rosyjskim (юбилей). Łaciński pierwowzór stał się podstawą słowotwórczą polonizmu, który $\mathrm{z}$ tego względu zawiera morfem -usz. Do języka rosyjskiego natomiast za czasów panowania cara Piotra I,

8 Wyraz ten występuje $\mathrm{w}$ formie mpoфeŭ $\mathrm{w}$ hasłach słownikowych różnych leksykonów, m.in. трофей [hasło], w: J. Wawrzyńczyk, Mały stownik rosyjsko-polski, polsko-rosyjski, Warszawa 2006, s. 335; mpoфeŭ [hasło], w: Słownik rosyjsko-polski, red. I.H. Dworecki, Warszawa 1949, s. 751.

9 Por. cnupm [hasło], w: ESJR, t. 3, s. 735.

10 Pojawiające się w wygłosie zapożyczonych leksemów głoski $s$ oraz $z$ były przekształcane w $s z$ oraz $\dot{z}$ (por. anyż [hasło], w: A. Brückner, Stownik etymologiczny języka polskiego, wyd. 6, Warszawa 1993, s. 5).

11 Teza ta została wysnuta przez Gorjajeva i powtórzona przez Vasmera. „Bозм., через франц. sanitaire «относящийся к здравоохранению» + суф. -ар(Горяев, ЭС 451)”. Por. санитар [hasło], w: ESJR, t. 3, s. 557.

12 Por. jubileusz [hasło], w: Stownik języka polskiego, red. W. Doroszewski, wersja online: http://doroszewski.pwn.pl/haslo/jubileusz/ [dostęp: 16.04.2014]. 
na drodze niemiecko-rosyjskich kontaktów językowych, został zapożyczony leksem Jubiläum ${ }^{13}$, który zmodyfikowano: doszło do odrzucenia końcówki -um, a pod wpływem wymowy głoski $\ddot{a}$ pojawiła się w wygłosie dwugłoska -ей, dając ostatecznie formę юбилей.

\section{Końcówka - $a$ w polskich rzeczownikach rodzaju męskiego}

Słowa akrobata, humanista i inwalida to rzeczowniki rodzaju męskiego, jednakże w polszczyźnie w liczbie pojedynczej odmieniane są według żeńskiej deklinacji, jak wyraz wojewoda. W wyrazach tych końcówka - $a$ została wytworzona na gruncie języka polskiego, w greckim i łacińskich pierwowzorach ona nie występuje (gr. akrobatos, łac. humanistas, łac. invalidus). W języku rosyjskim leksemy te funkcjonują w formie bezkońcówkowej i tym samym акробат, гуманист oraz инвалид są rzeczownikami rodzaju męskiego.

\section{Lacińska końcówka - $a$ w rzeczownikach rodzaju męskiego}

Języki słowiańskie przejęły z łaciny grupę wyrazów nazywających profesję, zachowanie lub postawę mężczyzny. Słowa atleta (gr. athletes, łac. athleta), idiota (gr. idiotes, łac. idiota), poeta (gr. poietes, łac. poeta), patriota (gr./łac. patriota) oraz patriarcha (gr. patriaarches, łac. patriarcha) są rzeczownikami rodzaju męskiego, jednak odziedziczona $\mathrm{z}$ łaciny końcówka fleksyjna - $a$ powoduje, iż wyrazy te odmieniają się w polszczyźnie w liczbie pojedynczej według żeńskiej deklinacji. W języku rosyjskim występują one w formie bezkońcówkowej: атлет, идиот, патриарх, патриот i $n o э m^{14}$, a ponadto wspomniane rzeczowniki rodzaju męskiego odmieniają się według II deklinacji. Do ruszczyzny wyrazy атлеm, идиот, nатриот і поэт zostały zapożyczone przy udziale niemieckiego lub francuskiego pośrednictwa (do derywacji wstecznej doszło na gruncie tychże języków zachodnioeuropejskich). Ze względu na

13 Por. юбилей [hasło], w: ESJR, t. 4, s. 525.

14 Por. T. Rott-Żebrowski, Różnice fonetyczne $w$ zapożyczeniach greckich w języku polskim i rosyjskim, „Slavia Orientalis” 1971, z. 2, s. 175. 
przynależność do religijnego kręgu tematycznego jedynie wyraz nampuapx przedostał się do języka rosyjskiego bezpośrednio $\mathrm{z}$ greki: najpierw funkcjonował w języku cerkiewnosłowiańskim, a później w języku rosyjskim. W wypadku tego słowa nie można mówić o odrzuceniu łacińskiej końcówki $-a$, ale o derywacji wstecznej morfemu -es.

\section{Końcówka fleksyjna - $a$ w rzeczownikach rodzaju żeńskiego}

Wyrazy analiza - анализ, anoda - анод, diagnoza - диагноз, dioda - диод, fasola - фасоль, gliceryna - глицерин, katoda катод, metoda-метод, narkoza - наркоз, pепісуlina - пенициллин, prognoza - прогноз, recepta - peuеenm, witamina - витамин w polsko- i rosyjskojęzycznych wariantach różnią się końcówką fleksyjną oraz rodzajem gramatycznym. W polszczyźnie, jak również $\mathrm{w}$ innych językach słowiańskich ${ }^{15}$ (głównie w języku czeskim, chorwackim, macedońskim, serbskim, czasem również w słowackim i słoweńskim), wyrazy te stały się rzeczownikami rodzaju żeńskiego poprzez dodanie końcówki - $a$, która nie występowała w ich greckich i łacińskich odpowiednikach (gr. analysis, gr. anodos, gr. diagnosis, gr. dis/hodos, gr. phaselos $>$ łac. phaselnes, gr. glykeros, gr. kathodos, gr. methodos > łac. methodus, gr. narkosis, łac. penicillinum, gr. prognosis, łac. vita + amine). Natomiast we wszystkich językach wschodniosłowiańskich oraz bułgarskim, należącym do grupy południowosłowiańskiej, leksemy te funkcjonują w formie bezkońcówkowej i w rezultacie stały się rzeczownikami rodzaju męskiego.

W wyekscerpowanym materiale występują tylko dwa wyrazy, które utrzymały łacińską końcówkę - $a$ zgodnie $\mathrm{z}$ obcojęzycznym

15 Pol. analiza, czes. analysa, sł. analiza, chor. analiza, serb., mac. анализа; pol. anegdota, czes. anekdota, chor., sł., anegdota, serb., mac. анекдота; pol. anoda, czes., chor., sł., słń. anoda, mac., serb. анод; pol. fontanna, czes., chor., sł. fontana, mac., serb., фонтана; pol. katoda, czes., chor. katoda, serb. катода; pol. metoda, czes., sł., słń. metoda; pol. narkoza, czes., chor., słń. narkoza, serb., bułg., mac. наркоз; pol. prognoza, chor., prognoza, mac., serb., buł. Прогноза; pol. recepta, bułg. peuеnта (por. П.Я. Черных, Историкоэтимологический словарь современного русского языка, t. 1-2, Moskwa 1999). 
pierwowzorem. W polszczyźnie, podobnie jak w łacinie, używana jest forma recepta (łac. recepta) oraz anegdota (gr. anegdota, łac. anegdota), w przeciwieństwie do języka rosyjskiego, na którego płaszczyźnie doszło do derywacji wstecznej końcówki - $a$, co spowodowało omawianą już wcześniej zmianę rodzaju gramatycznego z żeńskiego na męski.

W wyselekcjonowanym materiale wyjątki stanowią leksemy problem, program, system i telegram, które w języku polskim występują w rodzaju męskim. Na gruncie języka polskiego doszło do usunięcia końcówki fleksyjnej - $a$, występującej w greckich i łacińskich formach tych wyrazów (gr./łac. problema, gr./łac./nm./fr. programma, gr./łac. systema, gr. tele / gramma). W wariancie rosyjskojęzycznym została utrzymana forma fleksyjna $\mathrm{z}-a$ w leksemach: проблема, программа, система, телеграмма, dlatego też zakwalifikowano je do rzeczowników rodzaju żeńskiego.

\section{Sufiks -op [-or] w polsko- i rosyjskojęzycznych rzeczownikach}

Genetycznie wywodzący się z łaciny sufiks -or jest przyrostkiem, który funkcjonuje w wielu językach europejskich, w tym również w polszczyźnie i ruszczyźnie ${ }^{16}$. W wyselekcjonowanym materiale tylko w dwóch leksemach (gr. architekton/ łac. architector oraz łac. littetator) widoczna jest różnica o charakterze morfologicznym. W rosyjskojęzycznych wariantach kontynuowano sufiks -or, natomiast w języku polskim doszło do derywacji wstecznej. Taka opozycja widoczna jest w słowach architekt - apхитектор oraz literat-литератор.

W słowniku bazowym występują również słowa (łac.: director, operator, professor, rector, venilator), które w obu językach zachowały cząstkę -or, są to: dyrektor - директор, operator - onepamop, profesor-nрофессор, rektor-ректор і wentylator-вентилятор.

\footnotetext{
16 Por. M. Walczak-Mikołajczakowa, -or/-op/-op, w: eadem, Stowotwórstwo agentywnych nazw osobowych $w$ języku polskim, rosyjskim $i$ butgarskim, Poznań 2000, s. 42-44.
} 


\section{Morfem -up- [-ir-] w rosyjskojęzycznych czasownikach}

Przedostające się do języków słowiańskich czasowniki o greckiej i łacińskiej proweniencji ulegały przekształceniom formalnym, których celem było dostosowanie ich do systemów gramatycznych języków biorców. W wyekscerpowanym materiale występuje grupa wyrazów zakończonych sufiksem -owaćl-oвamb, jednakże jedynie w ruszczyźnie pojawia się dodatkowy morfem -up-. Czasowniki zawierające przyrostek -ировать stanowią na gruncie języka rosyjskiego dość młodą, bo powstałą za czasów panowania cara Piotra I, kategorię, której początek dały czasowniki niemieckie lub zapożyczone przy germańskim pośrednictwie zakończone na -ieren ${ }^{17}$. Te słowa zostały włączone do rosyjskiego systemu gramatycznego za sprawą sufiksu -оваmb, dlatego też współcześnie tworzone są nowe czasowniki, których podstawę słowotwórczą stanowią leksemy rodzime oraz zapożyczone z języków europejskich. W języku rosyjskim czasowniki zakończone na -ировать związane są głównie $\mathrm{z}$ terminologią społeczna, polityczna, naukową, techniczną oraz wojenną. W większości są to jednak terminy łacińskie, czasem greckie, określane mianem internacjonalizmów ${ }^{18}$.

W słowniku bazowym zanotowano następujące słowa zawierające morfem -оwaćluровать: agitować - агитировать, demonstrować демонстрировать, dyrygować - дирижировать ${ }^{19}$, informować информировать, konserwować - консервировать, kwalifikować квалифицировать, reagować - реагировать, regulować - регулирoвamb. Ich łacińskimi pierwowzorami były: agitare, demonstrare, dirigere, informare, conservare, qualificare, re agare, regulare.

${ }^{17} \mathrm{~W}$ języku niemieckim dyftong ie $\mathrm{w}$ wymowie zbliżony jest do samogłoski $i$, dlatego też $\mathrm{w}$ języku rosyjskim morfem ten ma graficzną postać -ir- [-up-]. Por. А.С. Дзедзич, Современное ударение в глаголах на -ировать, w: XXXIV неделя науки СПбГПУ: материаль Всероссийской межвузовской научнотехнической конференци студентов и аспирантов: 28 ноября - 3 декабря 2005 2., Sankt Petersburg 2006, http://elib.spbstu.ru/dl/007459.pdf/view [dostęp: 14.04.2014]; Глаголы, w: Современный русский язык. Активные проиессы на рубеже веков, ред. Л.П. Крысин, Moskwa 2008, s. 647.

18 Por. Образование глаголов на -ировать, w: Современный русский язык. Морфология (курс лекиий), ред. В.В. Виноградов, Moskwa 1952, s. 263-264.

19 W języku rosyjskim występuje spółgłoska $\nsim$ pod wpływem francuskiej wymowy głoski $g$ po samogłosce $i$. 
Dla podkreślenia, że powyższe leksemy przedostały się do języka rosyjskiego przy germańskim pośrednictwie, warto podać również niemieckie warianty tychże wyrazów: agitieren, demonstreieren, dirigieren, informieren, konservieren, qualifizieren, reagieren.

\section{Zakończenie}

Podjęty przeze mnie temat miał przede wszystkim uzmysłowić, że znaczny zasób leksemów występujących w językach pokrewnych instynktownie odbierany jako podobny, a niekiedy wręcz tożsamy w rzeczywistości ma wspólny rdzeń, który w wyniku adaptacji na gruncie języka polskiego i rosyjskiego uległ większym bądź mniejszym modyfikacjom językowym.

Przedstawiony problem adaptacji morfologicznej zapożyczeń greckich i łacińskich w języku polskim i rosyjskim to zaledwie wycinek zagadnień dotyczących słownictwa wspólnego. Z wyżej przeprowadzonych analiz wynika, że modyfikacje o charakterze morfologicznym miały na celu dostosowanie grecyzmów, greko-latynizmów i latynizmów do systemów leksykalnych obu języków słowiańskich. Analiza dotyczyła przede wszystkim adaptacji słowotwórczych, które zmieniając budowę wyrazu, wpływały zarazem na rodzaj gramatyczny oraz odmianę leksemów. W zgromadzonym materiale leksykalnym na gruncie polszczyzny można zauważyć pewną skłonność do przejmowania postaci łacińskich wraz z końcówką fleksyjną oraz rodzajem gramatycznym, co widoczne jest w niektórych słowach zakończonych na -um (archiwum), -us (spirytus) oraz - a (poeta) w rzeczownikach rodzaju męskiego. W ruszczyźnie zaledwie w czterech wyrazach (аквариум, пленум, президиум, техникум) wуstępuje morfem -um, w pozostałych doszło do derywacji wstecznej łacińskich końcówek i zastappienia ich rodzimymi wariantami: -ий (гербарий), -ей (лицей), -ия (коллегия) bądź wersją bezkońcówkową (центр). Konsekwencją tych zabiegów lingwistycznych była zmiana rodzaju gramatycznego oraz sposobu odmiany wyrazów w języku rosyjskim. Wyekscerpowany materiał potwierdził, iż w obu językach łaciński sufiks -or funkcjonuje $\mathrm{w}$ wielu pożyczkach, takich jak profesor - npoфeccop czy rektor - peктор. Innowacją względem polskojęzycznych 
wariantów wspólnych pożyczek jest pojawianie się morfemu -upw rosyjskich czasownikach (azumuроваmb).

W obu językach funkcjonuje spora grupa słownictwa wspólnego. Część to dziedzictwo prasłowiańskie, część - zapożyczenia z innych języków, głównie europejskich, ale także wzajemne pożyczki leksykalne między językiem polskim oraz rosyjskim. Zapożyczone słownictwo tylko w niewielkim stopniu nie uległo modyfikacjom. Mimo szeregu dokonywanych w procesie adaptacyjnym zmian o charakterze morfologicznym i fonetycznym wspólne zapożyczenia nadal są wariantami tych samych wyrazów.

\section{Bibliografia}

\section{Opracowania polskojęzyczne}

Brückner A., Stownik etymologiczny języka polskiego, wyd. 6, Warszawa 1993.

Chlebda B., Danecka I., Milutina T., Имя существительное, w: B. Chlebda, I. Danecka, T. Milutina, Skrypt do praktycznej nauki języka rosyjskiego dla studentów I roku filologii rosyjskiej, Opole 2007, s. 30-58.

Froelichowa M., Kwiatkowski M., Łaszewski S., Gramatyka języka rosyjskiego, Warszawa 1962.

Rott-Żebrowski T., Różnice fonetyczne $w$ zapożyczeniach greckich $w$ języku polskim i rosyjskim, „Slavia Orientalis” 1971, z. 2, s. 165-179.

Stownik języka polskiego, red. W. Doroszewski, t. 1-11, Warszawa 1958-1969, wersja online: http://doroszewski.pwn.pl/ [dostęp: 24.04.2014].

Stownik rosyjsko-polski, red. I.H. Dworecki, Warszawa 1949.

Walczak-Mikołajczakowa M., -or/-op/-op, w: M. Walczak-Mikołajczakowa, Stowotwórstwo agentywnych nazw osobowych $w$ języku polskim, rosyjskim i butgarskim, Poznań 2000, s. 42-44.

Wawrzyńczyk J., Mały słownik rosyjsko-polski, polsko-rosyjski, Warszawa 2006.

\section{Opracowania rosyjskojęzyczne}

Глаголы, w: Современный русский язык. Активные прочессы на рубеже веков, ред. Л.П. Крысин, Moskwa 2008, s. 647.

Даль В., Тольковый словарь живого великорусского языка, Moskwa 1903-1909.

Дзедзич А.С., Современное ударение в глаголах на -ировать, w: XXXIV неделя науки СПбГПУ: материаль Всероссийской межвузовской научнотехнической конференции студентов и аспирантов: 28 ноября - 3 декабря 
2005 2., Sankt Petersburg 2006, http://elib.spbstu.ru/dl/007459.pdf/view [dostęp: 14.04.2014] .

Карманный польско-русский и русско-польский словарь. Stownik kieszonkowy polsko-rosyjski i rosyjsko-polski, red. И.Митронова, Г.В.Синицына, Г.Липкес, Moskwa 1975.

Образование глаголов на -ировать, w: Современный русский язык. Морфология (курс лекиий), ред. В.В. Виноградов, Moskwa 1952, s. 263-264. Черных П.Я., Историко-этимологический словарь современного русского языка, t. 1-2, Moskwa 1999.

Фасмер М., Этимологический словарь русского языка, t. 1-4, Moskwa 1964-1987.

\title{
Morphological adaptation of Greek and Latin lexical borrowings in Polish and Russian
}

\author{
SUMMARY
}

As the common lexical borrowings are often considered only those lexemes that show absolute semantic and visual compliance. I included to this group also lexemes that are identical in terms of meaning, have a common formative base, however, as a result of development of various languages has been undergone a phonetic and grammar changes.

The purpose of this article is to present selected adaptation that have influenced the final form of borrowed Greek and Latin lexemes on the basis of Polish and Russian language. The analysis focused mainly on formative adaptation, which changed construction of the word modified noun's gender and type of declination.

Key words: Polish language, Russian language, morphological adaptation, lexical borrowings. 


\section{O Autorce:}

Sonia Behrendt-Bartkowska - doktorantka w Zakładzie Lingwistyki Antropologicznej Instytutu Filologii Polskiej Uniwersytetu im. Adama Mickiewicza w Poznaniu. Zajmuje się przede wszystkim porównywaniem leksyki funkcjonujacej w jezyku polskim i rosyjskim. Ponadto w obszarze jej zainteresowań pozostaja: wyrazy pochodzenia obcego w polszczyźnie i ruszczyźnie, glottodydaktyka, jezykoznawstwo porównawcze.

E-mail: sonia.behrendt@amu.edu.pl 